Carole Hillenbrand, Professorial Fellow, School of Medieval History, University of St Andrews, St Andrews, UK

Robert Hillenbrand, Professorial Fellow, School of Art History, University of St Andrews, St Andrews, UK

\begin{abstract}
This article presents the first full English translation of the Arabic text of that portion of Rashid al-Din's Jami “al-Tawarikh ("World History") which deals with five of the earliest Pishdadian or mythical kings of Iran. This text has a particular importance in that it dates from the lifetime of the author. Its content is distinctively different from that of the much longer and better-known narrative of Firdausi that deals with these monarchs. It is thus a reminder of the co-existence of several versions of this material. Alongside a brief commentary on the text itself, the article considers the role and content of the four paintings that accompany it, focusing on how they interpret the accompanying text, their storytelling techniques, their evocation of the Ilkhanate court and how far they presage future developments in Iranian painting.
\end{abstract}

\title{
ANCIENT IRANIAN KINGS IN THE WORLD HISTORY OF RASHID AL-DIN Carole and Robert Hillenbrand
}

Four of the most celebrated ancient kings of Iran make a perfunctory and somewhat unexpected appearance in the pictorial cycle of the Edinburgh fragment of the Jami ' alTawarikh or World History of Rashid al-Din (d.1318), produced in Tabriz, the Mongol 
capital of Iran, in the lifetime of the author. ${ }^{i}$ The relevant text, with its accompanying images, comes almost at the beginning of the manuscript in its present truncated form - for the volume lacks both a frontispiece and the appropriate introductory matter. This was removed at an indeterminate date. So now it begins in medias res, describing the wonderful city of Iram, though the current $\mathrm{f} .1 \mathrm{a}$ is probably quite close to the original opening of this chronicle. ${ }^{\text {ii }}$ The text on these Persian kings is now found on folios $2 \mathrm{a}$ to $3 \mathrm{~b}$ and is thus sandwiched between a detailed account of the pre-Islamic Arab prophets, Hud and especially Salih, and brief presentations of the life of Abraham (who is allotted a single image) and some of his descendants (none of whom rates a picture), followed by a lengthy though curiously incomplete narrative of the life of Moses ${ }^{\text {iii }}$ which segues into the story of Joshua. So these ancient Iranian kings, while not prophets themselves - though Rashid al-Din notes that nonArabs regard Tahmuras as a prophet ${ }^{\mathrm{iv}}$ - are presented to the reader in the context of salvation history rather than mere chronology. This heightens their status within the predominantly Islamic ambience of the text. It may even represent an attempt to give the Iranian tradition its place in the sun alongside the more established Iranian and Hebrew prophets.

The presence of personalities from the Shahnama in a history of the world, particularly one written in Iran, is not strange in itself. But the insertion of secular matter into the sacred history that was the normal starting point for universal chronicles does, as already noted, give one pause. Moreover, while this is a short passage of text, its four accompanying illustrations - one for each of the four kings mentioned and each following close after the previous one - serve to give it extra prominence. And given the generous length allotted to the accounts of the prophets before and after this short passage, its sheer brevity is also noteworthy. Nor is it easy to explain why only four of the many kings mentioned in the Shahnama should be introduced at this point, and why the passage should end with an abrupt transition from the death of Zahhak to the birth of Abraham. Why are these two personalities, 
polar opposites to each other, presented cheek by jowl? Zahhak, after all, is a creature of Iblis, the devil, while Abraham is one of the supreme prophets of God. Mere chronology is the reason given in the text for this strikingly inept juxtaposition: "And because the birth of Abraham (peace be upon him) was in the days of al-Dahhak, it is necessary to give an account of him". ${ }^{\circ}$ And in the absence of any attempt to propose a date for the personalities discussed in this section of the manuscript, chronology is better than nothing as a device to organise disparate material. But such crashing discords - and also major unexplained omissions - render this text enigmatic.

As it happens, previous scholarship has not tackled these questions in appropriate detail, although a welcome recent article by Charles Melville ${ }^{\mathrm{vi}}$ has broached the wider issue of Rashid al-Din and the Shahnama. His main focus is on the historiography of the Persian text of Rashid al-Din and its relation to the material on the early Persian kings in the Persian texts of Bal'ami, Baidawi, and Hafiz-i Abru, and he makes only limited reference either to the Arabic text of the Edinburgh fragment or to the images that accompany it. In fact it is striking that Rashid al-Din's treatment of the five Pishdadian kings discussed in the present article clearly comes from a tradition substantially different from several of the versions in Persian discussed by Professor Melville, though two of those are clearly related, as he shows, to the Edinburgh fragment. The present article is therefore a natural pendant to his and offers ample material for future researchers to compare these versions in the requisite detail. It will present the first translation of Rashid al-Din's unedited and hitherto untranslated Arabic text that deals in sequence with Kayumars - who, despite his importance as the ancestor of mankind, is not allotted an illustration - Hushang, Tahmuras, Jamshid and Zahhak; it will comment, in necessarily brief and preliminary fashion given the scope of this article, on that text; and it will analyse the images themselves in depth. 
One significant context for the text and pictures dealing with the ancient Persian kings in the Edinburgh fragment is the sudden boom in the production of illustrated Shahnama manuscripts in the period c. 1300 to c. $1350 .{ }^{\text {vii }}$ While only a single literary reference to an earlier illustrated Shahnama has come to light - it was made for a Qarakhanid monarch in the late $12^{\text {th }}$ century ${ }^{\text {viii }}$ - there are sufficient pointers to the use of scenes or figures from the Shahnama on luxury lustre ${ }^{\mathrm{ix}}$ and mina ${ }^{\mathrm{x}}{ }^{\mathrm{x}}$ ceramics in the pre-Mongol period to indicate that potters at least had begun to recognise the value of the Shahnama as a quarry for visual material. Metalworkers were not far behind. ${ }^{\mathrm{xi}}$ And the presence of lengthy Shahnama inscriptions on lustre tiles decorating the palace of the Mongol Ilkhan Abaqa at Takht-i Sulaiman in 1265 is collateral evidence of interest in Firdausi's text at the highest level of government. ${ }^{\text {xi }}$ But none of this adds up to the development of anything approaching an iconography of the Shahnama. Given the total absence of surviving Shahnama illustrations in manuscripts before c. 1300 , then, this boom, which is represented by manuscripts containing in total hundreds of illustrations ${ }^{\mathrm{xiii}}$ - and the 8 Shahnama images in Bal'ami's Persian summary of al-Tabari's History should be added to this total ${ }^{\mathrm{xiv}}$ - represents a seachange of massive proportions in the art of the Ilkhanids. The illustrated book had well and truly arrived, and was attracting the patronage of the wealthiest members of society, at least some of whom held the highest rank. ${ }^{\mathrm{xv}}$ It was inevitable that a luxury illustrated Shahnama should be produced for the sultan himself, and the Great Mongol Shahnama - by far the finest illustrated manuscript of its time - duly met this need. ${ }^{\mathrm{xvi}}$ When the text and images of the ancient Persian kings inserted somewhat awkwardly into the World History of Rashid alDin are considered in this wider context, they make excellent sense as an expression of a contemporary fashion. But it is hard to ignore that awkwardness, and one cannot avoid the conclusion that this Shahnama material does not fit easily into Rashid al-Din's chronicle. Indeed, it feels like something of an afterthought. Moreover, at best the treatment of the 
Shahnama in Rashid al-Din's text is piecemeal. The only passage which is not linked to a king is the death of Rustam, whose inclusion in this text is something of a puzzle; so the adventure element in the Shahnama is virtually unrepresented. But it would be wrong to give the impression that it was in the $14^{\text {th }}$ century that the Shahnama first made an appearance in ambitious universal histories; early Iranian kings figure, for example, in the narratives of alTabari and Ibn al-Athir among others. ${ }^{\text {xvii }}$

That said, it is only fair to point out that the Edinburgh fragment, which totals 150 folios and was originally twice as long, is strangely put together. ${ }^{\text {xiii }}$ What comes across is a rather jumbled version of universal history, chaotic in its presentation and innocent of any attempt to detect a pattern in events or to drive home over-arching ideas or interpretations. It is by no means an organic whole. Its emphases are erratic. Thus Abraham is comprehensively overshadowed by Moses, ${ }^{\text {xix }}$ yet the story of Moses, long though it is in this manuscript, is strangely lacunary, and indeed only a few somewhat random portions of the Old Testament figure in the Edinburgh fragment. The absence of Solomon is especially noticeable. The focus then shifts to the Shahnama again, but once more there is no attempt to present a continuous narrative, even in the most reduced form; instead, isolated episodes are interspersed with tales taken from the Old Testament. Thereafter, a brief account of the Virgin Mary is followed by the early life of the Prophet Muhammad, which is presented in consistent detail, though there is no mention of events after the hijra. For the period from 622 to the late $10^{\text {th }}$ century, which accounts for some 50 folios, the text is very concise and indeed is more of a précis than a substantial narrative. And then, at folio 107, with scarcely any warning, it presents a long, detailed history of the Ghaznavids, with brief excurses on other contemporary dynasties. The literary style of this section of the manuscript is often florid and extravagant, and the level of detail can be overpowering. It seems safe to assume that this is not the work of Rashid al-Din, and that he is reproducing the work of another chronicler. 
Perhaps this particular copy of Rashid al-Din's text was intended to be sent to a destination in the eastern part of the Ilkhanid domains - perhaps to some city in Khurasan like Herat, Nishapur or Marv. At f.138a the pictorial narrative switches to the Saljuq dynasty, whose fortunes are recounted up to the time of Tughril III, who died in 1194. By any count, that is an uneven and idiosyncratic account, even when one bears in mind that half of the original manuscript is missing - a marginal note states that it was stolen ${ }^{\mathrm{xx}}$ - with no clue as to what it contained.

It should be stressed that this odd mixture of unrelated bits and pieces of history is not due to the fragmentary nature of the sources available to Rashid al-Din. For much of the material he covers, especially the scenes from the Old Testament and the life of Muhammad, the sources are full and easily available. Even for Islamic history after the death of the Prophet, there would have been no shortage of sources to use. But they have been ruthlessly gutted by whoever put this particular version of Rashid al-Din's text together, and the reasons behind this curious mélange of very disparate material, including the nature of the audience at which it was aimed, await explanation. That is a challenge for future research.

It is now time to consider the nature of Rashid al-Din's treatment of early Iranian history - if "history" is the right word for an account so redolent of myth - and, in due course, the role played by the paintings that accompany this rather jejune text. Jejune it may be, but in its Arabic version this text has so far scarcely received any close attention from scholars, and so the translation will take pride of place here. On f.1b Rashid al-Din sets the scene as follows: "The beginning of the account of the kings of al-Furs and the events which happened in the time of each of them, from the appearance of the prophets, and events other than this, from the time of Kayumars until the end of the period of Ibn Dajrdin Shahriyar, the last of the kings of the non-Arabs.... The first of those who held the sultanate and brought it into the world was Kayumars." He goes on to state (f. 2a) that "the 'ulama' of Fars have agreed that 
Kayumars was Adam... and that all created beings are among his descendants and his children. They say that he had a son called Masha and a daughter called Mashan. They married each other and two sons were born to them, Siyamak and Siyami, and from their coupling sons were born. The name of the eldest was Farwal and he had a sister whose name was Afarin. Farwal married his sister, and Hushang who was the father of the Persians and Qar who was the father of the Arabs were born." The obscurity of this passage is typical of Rashid al-Din's account of the Pishdadiyan. Indeed, he goes on to cite the various views held by scholars about Kayumars: that he was Noah's son Ham; that he was one of the sons of Arpachshad b. Shem; and that he was Noah. But it is noticeable that the initial opinion that he cites is that Kayumars was Adam, and that therefore mankind began in Iran. Rashid al-Din continues: "The majority consensus is that the building of the country was begun by him. His sultanate lasted thirty years and the birth of Hushang came 223 years after his death. He became sultan 295 years after the death of Kayumars, and they called him Shaddad... The first of the sultans and kings of Fars were from his lineage and they have been arranged in four generations in this exposition: the Pishdadian, the Achaemenids, the Askaniyya, the Sasanians." ${ }^{\text {xxi }}$ Rashid al-Din summarises the rule of the early kings by noting that it lasted 2,735 years, comprising the rule inter alios of Kayumars for thirty years, Hushang for forty years; Tahmuras for thirty years; then Jamshid for 700 years; Zahhak for 1000 years; Faridun for 500 years, Manuchihr for 120 years and finally the much shorter reigns of Nuwadar, Afrasiyab, Zuin Tahmasb and Kishashab. He makes no comment on the huge disparities in the length of the reigns of these monarchs.

He then doubles back, launching into a new section entitled "the rule of Hushang ${ }^{\text {xxii }}$ and his picture", which follows immediately (pl.1). Beneath the painting the text continues: "He was knowledgeable and just. Amongst what is attributed to him is the book Jawidan Khirad $^{\mathrm{xxiii}} \ldots . .$. And his capital was Istakhr and there he ${ }^{\mathrm{xxiv}}$ sat on the throne of the kingdom. 
The non-Arabs assert that he was a prophet. He held command of the sultanate for a period of forty years. He was the one who established the custom of placing the crown on the heads of kings and he extracted iron from stone and made weapons from it. He built many more buildings in Istakhr, which was the seat of the kingdom of Kayumars, and he built up the two towns Babul and Sus, which is now the burial place of Daniel... Most people mention that Zahhak built it..." ${ }^{\circ x v}$ Rashid al-Din continues:

"The account and picture of Tahmuras."xxvi (pl.2) "He is Tahmuras ${ }^{\mathrm{xxvii}}$ b. Anujihan b. Anukhahd $b$. Hushang. He is the one who conquered the seven climes and he became established instead of Hushang. He championed the citizens and the protection of the kingdom and he walked the road of justice and equity. He continued in the sultanate for a period of three hundred years. He built Kaharrdar (?) in Marv ${ }^{\mathrm{xxvii}}$ and he restored the two towns of Marbin ${ }^{\mathrm{xxix}}$ and Saruya in Isfahan. Marbin is now a village and it is known by another name. And Saruya is now a quarter. Some people attribute the building of Nishapur and Fars to him. ${ }^{\mathrm{xxx}}$

In his time the worship of idols appeared. The cause of that was that in some buildings a plague of frogs occurred in which many people perished. Everyone who died had a family member or a relation who took a statue in his image. He looked at it and visited it and he found comfort in looking at it. That became established to such an extent that it became a custom and ceremony for the whole period and time until idols were worshipped. In his time fasting was also revived. The reason for that was that a group of wretched poor people found it a struggle to find food. They were deprived and were not eating anything in the daytime; indeed, every day and night they ate a single meal in the evening and they were satisfied with that. And wherever the days continued for them in that manner, that became a permanent custom....When Islam came they became Sabians. Some of them mentioned that the reason for fasting was that in the time of Tahmuras the people suffered from drought and 
there was a great lack of rain. He ordered the $\ldots{ }^{\text {xxi }}$ to be satisfied every day and night with one meal in the evening and that they should give what they had prepared to eat to the homeless. And that gradually became a well- known custom. And Tahmuras was called Tahmuras Riyawabad. ... He is the one who used to say that every group takes delight in its belief and religion." "xxxii

Rashid al-Din's account of Kayumars, Hushang and Tahmuras is translated here in extenso to give the flavour of this text. Several features are worth noting, though there is not enough space in this article to develop them in full, let alone to outline their place in the historiographical tradition, their context and their implications. The text is plainly derivative, but the specific sources on which Rashid al-Din drew are not cited, nor does he comment on their reliability. The author has not tried to collate the very disparate information that his account contains. The rambling quality of this narrative betrays its lack of organization. It contains troubling inconsistencies, for example in its contradictory accounts of the parentage of Kayumars and of Hushang, or the length of the royal reigns. It is full of unrelated snippets of information. The genealogical information is confused. These same features can also be detected in his accounts of Jamshid and Zahhak, which now follow.

Rashid al-Din says rather more about Jamshid (pl.3) than he does about Hushang and Tahmuras, but here too (f.2b) he presents a farrago of facts innocent of any integrated narrative. The full text reads:

"The account of Jamshid b. Nujahan.

He is the brother of Tahmuras and his name was Jam and Shid, the one possessed of radiant rays. He had perfection of beauty, splendour of form, and purity of face and purity of colour. He was called Jamshid, and together with the abundance of his beauty and his aforementioned splendour, he had knowledge and intellect. The nobles of Fars gathered to him and they gave him precedence over themselves, out of knowledge of the nobility of his 
position, and they swore oaths of servitude and submission and obedience to him. This is his picture [here the image of Jamshid is inserted] and he concerned himself with organising matters, improving the public weal, organising materials, devising weapons of war, designing crafts and building the town of Istakhr. He enlarged it and he had renovated it (f. 3a) ...... and he stretched it from its extremity and made it bigger. He calculated its measurement as twelve farsakhs in length and ten farsakhs in width and he built in it a great building, and there have remained of it now ruins and pillars of an extreme height to the degree that they are called the pillars of the column of forty minarets. There he sat on the throne of the kingdom at sunrise at the first point of the station of Aries, and that is called today Nauruz. He promised everyone justice, compassion and equity. Amongst all the great things which he authorised was the building of an aqueduct on the Tigris at al-Mada' in, ${ }^{\text {xxiii }}$ and it remained until the age of Alexander, and Alexander destroyed it. The ruins of it have remained until now from the western side of the Tigris near the construction of buildings and towns which were in al-Mada'in. Not one of the sultans could build the above-mentioned aqueduct after its destruction. They were incapable of it and they restricted themselves to the building of bridges. He was the one who built the town of Ctesiphon, ${ }^{\text {xxxiv }}$ one of the biggest towns in alMada'in. When he became established in the kingdom.....600 years and he became overweening in his kingdom, wealth, chattels, men and power, conceit invaded him, tyranny and foolishness overcame his temperament. He laid claim to divinity and he ordered the people to worship him and to make statues in his image. He sent them to the climes so that he might be worshipped. Almighty God sent to him al-Dahhak ${ }^{\mathrm{xxxv}}$ whom the Persians call Varasp and He gave him power over him. Al-Dahhak sought him out and he gained control of his state.....Jamshid fled, defeated, in hiding for a hundred years, driven away, fugitive, afraid of him, until the opportunity came to al-Dahhak. He took him by force and he cut him up piece by piece in captivity. The period of his rule was 700 years and he was defeated. Of 
those years he ruled for 600 years, expanding ......and for the period of 100 years he endured adversities.... sometimes defeated, sometimes fearful. God knows best.”

From the purely historical point of view, this passage is valuable on several counts. It associates Jamshid firmly with Fars and thus highlights the importance in the medieval historiographical context of southern and western Iran, the homeland of the Sasanians, as distinct from northern and eastern Iran, the homeland of the Parthians. It connects him with the founding of the festival of Nauruz. Before Jamshid falls from grace, the notion of farr, ${ }^{\mathrm{xxxvi}}$ the royal splendour that radiates from the legitimate king of Iran, is clearly implied. The passage also sheds light on how Jamshid was associated in medieval times with the ruins of Persepolis - hence the still popular appellation of the site as Takht-i Jamshid, "the throne of Jamshid" - and also with Istakhr, remembered by Muslims as a centre of pre-Islamic Iranian culture and often, as here, conflated with Persepolis. ${ }^{\text {xxxvii }}$ This is of a piece with the tendency to mythologise the majestic survivals of the architecture and sculpture of preIslamic Iran. Hence the cluster of Achaemenid and Sasanian remains just outside Persepolis is still popularly known as Naqsh-i Rustam; the gigantic unfinished rock sculpture near Taq-i Bustan is known as Tarash-i Farhad, and Taq-i Bustan itself became a repository for legends about Khusrau, Shirin and Farhad. ${ }^{\text {xxxviii }}$ There is no room here to explore the manifold implications of this potent brew of myth and history. One may also note that the image of Alexander as a great destroyer, a tradition fostered by the Zoroastrian priestly class, now extends beyond Iran proper into Mesopotamia.

Finally, what of Zahhak, or al-Dahhak as the Arabic text dubs him? (pl.4) Rashid alDin's text is so damaged and faded that in several places it resists decipherment, ${ }^{\text {xxix }}$ but what is legible may be rendered as follows:

(f.3a) "The account of al-Dahhak who is known as Bewarasp. ${ }^{\mathrm{xl}}$ There is disagreement about his genealogy. A group of Arabs mentioned that he was Ibn 'Alwan, the brother of Shaddad 
b. 'Ad, ${ }^{\text {xli }}$ and they traced his genealogy to Iram and Sam and Arfahshad, as was mentioned at first. It is said that Shaddad sent him to attack Jamshid. The Persians assert that his name is Bewar.asp b. Arwandasp b. Zinkaw b. Bads..r.h(?) b. Taz b. Farwal. And among their assertions is that Taz b. Farwal is the father of the Arabs, and that has already been mentioned too. It was said that he was called Bewarasp Dahal. Its meaning is that in him there was Wherever Arabic was spoken, Dahal was called Dahhak, 'the one who smiles'; that ugly title ${ }^{\text {xlii }}$ was made into a good one. The people of Yemen, amongst whom are the Seveners, say that Dahhak is derived from 'cheerfulness' and 'smiling'. He came from amongst them and he was the first of the Pharaohs. He seized power and established himself on the throne of the kingdom. This is his picture. (Here the image of Zahhak is inserted).

He began shedding blood and slaughtering. His rule lasted a thousand years and his tyranny over the citizens was continuous. They did not demand justice from him until the people tired of his behaviour. Finally two cracks appeared for him on.......... and with their image $\mathrm{e}^{\text {xliii }}$ on both his shoulders. He was unable to cure them both and he could nothing whatsoever. Iblis appeared to him in the image of a human being and said to him: 'The cure for that is to daub with the [brains] of the head of a human'. He could not daub with that at all. So he hid them both under his clothes and the people thought that they were two serpents......

He would take from the treasure of a town ........The citizens wrote that down and they felt oppressed by what he owed them. For this reason many people were killed.

There was from the people of Isfahan a person called Kava the Blacksmith. Two of his sons had been killed in this He went out and took the leather which the blacksmiths left on their [aprons] above their clothes if they wanted to work. He lifted that leather onto a piece of wood, he called the people to himself and reviled al-Dahhak. out 
of fear that he would kill their sons unjustly and tyrannically. So they went out of the town. When al-Dahhak heard that, he fled since he had no resistance against the populace. The people with Kava the Blacksmith were numerous and he took possession of that land. Since there was nobody from the family of the government, nobody came forward to claim the sultanate. Afridun son of Athfiyan from the sons of......... out of fear of al-Dahhak. The Blacksmith did not cease to search for him so that he could defeat him, and he sought him. The chiefs of the Persians agreed to appoint Afridun as head of the state. He had gone into hiding out of fear and they sat him on the throne of government. He sent helpers after al-Dahhak and they defeated and killed him. Afridun was victorious with troops and armies and he took that leather which was and they blessed him and called him Darafsh Kabiyan

[f.3b] The armies of Islam entered al-Mada'in and took possession of their king who was Darafsh Kabiyan with what they plundered from him and they brought him to the caliph 'Umar (may God be pleased with him) in Medina and he ordered them to cut him because of the jewels and rubies which al-Dahhak had distributed. Amongst the monuments of alDahhak was Babul on the borders of Iraq and the city of Damascus and Tyre in Syria. Aqlid.s was the architect of Tyre. And because the birth of Abraham (peace be upon him) was in the days of al-Dahhak, it is necessary to give an account of him."

As in the account of Jamshid, the story of Zahhak veers erratically and unpredictably across many lands (Arabia, Syria, Iraq and Iran) and epochs, from Abraham to the caliph 'Umar, who is introduced into the story almost by sleight of hand. After the well-nigh obligatory rehearsal of his genealogy, which is contested, as in the case of other Pishdadian monarchs, and of the etymology of his name -"he of the ten vices", or alternatively "the one who smiles" - Rashid al-Din notes Zahhak's Yemeni origin and calls him the first of the Pharaohs, the very exemplar of pride and tyranny. The problem with this account is that key 
words are missing or indecipherable, but the story as told in this rather confusing way by Rashid al-Din is well known from other sources, of which the fullest and most easily accessible is the Shahnama of Firdausi. In brief, its highlights are that the devil (Iblis), kissed him on both shoulders and from each of those imprints there issued a snake which tormented Zahhak and had to be fed daily by fresh human brains. This was the most grievous of the many injustices which Zahhak inflicted on his subjects, and eventually it caused the popular rebellion led by the blacksmith Kava which deposed Zahhak, though according to Rashid alDin it was Afridun (i.e. Faridun) who had him killed. There is no mention of Zahhak being fastened to Mount Damavand, as Firdausi describes, and dying of exposure, which in time became a cliché of Shahnama illustration. ${ }^{\text {xliv }}$ Afridun is presented as being a contemporary of the caliph 'Umar, while the passage ends by introducing Abraham, who was born in the reign of Zahhak. The time frame is thus thoroughly obscure.

The very terse accounts of the first three kings in Rashid al-Din's text give away very little to inspire the artist. Even so, some opportunities were missed, such as the accounts of a plague of frogs and the beginning of idol-worship in the reign of Tahmuras. In any case, it is clear that the person in charge of the illustrative programme - one might term him "The Master of Works" - decreed that there should be pictures for virtually every ruler mentioned in the text. This is perhaps a nod to the illiterate, who could instantly understand how many early, or at least important, rulers there were. Even so, in comparison with, say, Moses, where there is a meaty narrative, these kings are treated in rather summary fashion. Nevertheless, when the text is sufficiently informative, as in the cases of Jamshid and Zahhak, the artist does try to bring that information into the picture, as noted below. But even so, the Edinburgh fragment presents a history of the earliest Iranian kings that is notably sparse in relation to many of the versions written in Persian, though Professor Melville has underlined its connections with the Persian chronicle Nizam al-Tawarikh of Qadi Baidawi, composed 1275, 
and an undated Persian version of the World History in the British Library (B.L. Add. Ms. 7268). In short, in the case of the Pishdadian kings the Edinburgh text too often gives the minimum of context for the accompanying images.

It is now time to discuss in appropriate detail how the painter (or painters) interpreted the rather quirky texts on these mythical kings which they were required to illustrate. The four pictures crammed into folios $2 \mathrm{a}, 2 \mathrm{~b}$ and $3 \mathrm{a}$, two of them placed in quite exceptional fashion one below the other on folio $2 b,{ }^{x l v}$ are the first of a whole series of enthronement images in this manuscript. ${ }^{\text {xlvi }}$ No two illustrations of that series are identical, but their similarities are far more striking than their differences. There is no denying their formulaic character. The standard format places the ruler centre stage and flanked by bodyguards, or officials, or both. And in every case he is seated on a throne. Hence the unmistakably formal, ceremonial flavour of these scenes: this is the ruler on display, every inch a king. It is not the ruler at ease.

Often enough the overriding importance of the ruler is emphasised by the fact that he is so much larger than those around him, and by his commanding pose - the only figure in the picture to be depicted seated cross-legged, with his left hand clamped to his thigh. In all four images strict frontality, the traditional pose for asserting power and dominance, is abandoned in favour of a slight turning of the face to right or left, which underlines a connection between the ruler and his attendants or subjects and creates a sense of narrative. But the power and unique status of the monarch is sufficiently stressed by the fact that he wears a crown and is seated on a splendid throne while those who serve him stand or are hunched forward on a stool while engaged in writing, or indeed kneel submissively. Three of the four images - the exception is the enthronement of Hushang, which takes place in the open air employ the motif of a knotted and folded canopy, either folded in a continuous bolt or divided into swags and sometimes garnished by fluttering ribbons, whether these are pur[ple 
with a scarlet hem or deep blue and gold-spangled. It can serve either as backdrop or frame for the enthroned monarch. The idea of placing an honorific covering over the ruler of course has an ancient pedigree.

The oblong landscape format used for all four of these paintings favours a composition in which the figures are strung along the frontal plane, so that the eye moves naturally from one to the next. Thus the picture resolves itself into a sequence of discrete accents, most of them vertical. The occasional overlap does not affect this process; nor does the presence of seated or kneeling figures. So the artist can easily ring the changes on the formula from one painting to the next. But the effect nevertheless is to weaken the overall impact of an image. By contrast, a vertical or portrait format, or indeed a square one, allows a greater degree of visual build-up and concentration, a clearer and indeed better division between what is significant and what is not. That is harder to achieve in the oblong format, which favours large-sized figures and minimal detail. The setting itself varies from the natural to the neutral. The enthronement of Tahmuras in what looks like a garden chair made of bamboo takes place in a full-blown outdoor setting somewhat uneasily combined with the standard file of attendants.

The artist is unfazed by obvious anachronisms; thus Jamshid has his hair dressed in a long pigtail and has a mandarin square emblazoned on his caftan, and indeed in the case of Tahmuras the same design runs unbroken across its fold. ${ }^{\text {xlvii }}$ In fact East Asian elements are so predominant in all four pictures that these monarchs are Iranian in name only. ${ }^{\text {xlviii }}$ Although all of them wear crowns of broadly Saljuq type, and Turkic caftans, they sit on Chinese thrones with scarlet frames featuring languid curves and curled trilobed supports (also found on the scarlet footstools), plus brass fittings, including trilobed finials and others of dramatic dracontine form, and maroon upholstery dominated by Chinese floral forms such as the peony. The vertical sides of some of these thrones boast flat extensions in red and blue 
with bilobate leaves, hooked re-entrant curves and bulging globular protrusions. Beside the throne of Tahmuras stands a massive Chinese vase, apparently made of metal, with splayed foot, a rounded body with concave depressions and a tall neck carrying a much wider rim. Its sheer size announces its importance as a status symbol. A graceful rose-coloured orchid with wide leaves on a slender stem emerges from it and underlines the theme of exotic gracious living. A smaller, shorter and simplified version of that vase, obviously made of the same material with a design that similarly subdivides the squat globular body into adjoining compartments or cells, but now has circular handles and a bulging neck, is set in the foreground of the scene of Jamshid enthroned. It has long, narrow, spikey leaves and a quartet of blossoms. The faces of Tahmuras and Hushang are East Asian, with almond eyes, pencil moustaches and tiny single or double goatees, whereas both Jamshid and Zahhak are fully bearded. Most of the attendant soldiers or bodyguards are of distinctly East Asian appearance; they tend to be young and clean-shaven, and their hair follows various fashions: bunched below the ear, ${ }^{\text {xlix }}$ formed into a pigtail or shoulder-length and crimped. Older bodyguards are bearded and have their hair bunched at the back. The hats worn by the bodyguards have distinctive wide, sweeping broad or narrow brims, richly coloured and patterned, ${ }^{1}$ and high padded or quilted crowns topped with metal funnels, spikes ${ }^{\mathrm{li}}$ or lozenges, or a frontal badge. Some of these hats are trimmed with fur; others combine upturned and downturned crescent forms in contrasting red and blue, as in Tahmuras's bodyguard, or have double upturned brims in similar tones. Many further sub-varieties of hat occur in the later enthronement scenes, and this absence of standard forms provides cumulative evidence suggesting ${ }^{\text {lii }}$ that hats were a matter of personal choice and did not connote a particular office or rank. Hats of this kind seem not to figure in earlier Iranian art, which in turn indicates that they reflect contemporary fashions. 
The scene depicting Hushang is set in the open air, and like many a later enthronement in Iranian painting the surroundings are lush. The artist conjures up a landscape in a few sure strokes. A blossoming sapling rears up between two seated courtiers; its body bends extravagantly to mimic the curved posture of the courtier facing Hushang. The drooping foliage of a weeping willow cascades down from the upper frame on either side of the tree's dramatically twisted trunk, which has a jagged errant branch growing behind the main trunk and at almost right angles to it. This branch is cut off by the upper frame. The treatment of this tree, with its obligatory knobbly base and lightly sketched internal modelling, is intended to add visual interest to the right-hand section of the painting; it acts as a natural separator between the enthroned Hushang and the counsellor who sits next to him. It is a tree of a kind that recurs repeatedly in this manuscript, with a thickening and deepening of colour (in this case reddish purple) to emphasise its outline, which is further asserted by an expressive scattering of nodes and bulges in its bark. Towards the far right of the painting, and framing Hushang to his left, are the brown leaves and trunk of another tree whose base juts out at a pronounced fifty-degree diagonal in the direction of the vertical frame, drawing the eye to the bodyguard standing to Hushang's left and creating an alternative line of sight for the painting. It has the divided base so frequently found in the trees depicted in Ilkhanid painting. Other components of the standard landscape format used in this manuscript and featured here include the centrally placed and gently curved mound, the irregular patches of grass, rendered in black and red, that sprout along the black horizon lines or at the very bottom of the picture, and the depiction of secondary planes by means of a single black line. A sickle-shaped rock, ultramarine in colour, obscures the base of the tree to Hushang's right and another blue rock with a large round hole in it, marks the extreme right of the painting. These rocks are also borrowed Chinese features; rocks of unusual shape were a traditional element in Chinese garden design. 
Hushang's throne deserves more than merely passing notice, for it is of a kind not encountered elsewhere in this manuscript. It looks more like a garden chair than a throne, and this open-air function may explain the lack of a valance. It is only the artist's ambitious but unsuccessful attempt at a rational perspective view that gives it the appearance of a rocking chair. Its emphasis on slender lines and extravagant curves suggests that it is made of bamboo. The open decorative arches, conceived as separate panels rather than as a continuous arcade, are also a feature not found on the other thrones depicted in this manuscript.

The exact interplay between the heavily bearded balding courtier and Hushang is unclear, but since the former is holding out an open book, it may be that this is a copy of the king's work Jawidan Khirad - a manual of statecraft - mentioned by Rashid al-Din. Its leather binding is dyed crimson. The three seated figures in this painting are carefully distinguished from the royal soldiery by means of their dress. None of them wears the caftan that is standard issue for the bodyguards or courtiers wearing Mongol headgear; they all have a flowing under-robe that covers their arms and reaches right up to the neck, one coloured beige and the other two blue, with a looser and shorter brown garment thrown over it. The shaven-headed courtier has a more elaborate belted outer red robe. All of this clothing is indicated with the utmost economy by a few strokes in blue, brown or red to indicate folds. None of these seated figures wears any headgear and all are barefoot. Clearly, then, the artist is at pains to distinguish between the Iranians and the non-Iranians.

Admittedly, two monarchs are shown in not entirely stereotypical guise: Jamshid and Zahhak. These deserve separate treatment. The image of Jamshid has two unusual elements: first, the reference to weapons and secondly, the presence of a seated suppliant, bare-headed and barefoot, who is trying to catch the royal eye. In later centuries, Iranian painters concentrated on depicting Jamshid as teaching his people various crafts, ${ }^{\text {liii }}$ here the painter 
alludes to this detailed narrative merely by showing an attendant advancing on the throne with a pair of unstrung bows. Close behind is an attendant holding a sheathed sword. And this picture breaks with the standard formality of these early enthronement scenes by a telling detail: a watchful bodyguard restrains an obviously eager suppliant from interrupting the king as he gives his orders to various craftsmen. This little drama is played out by the interaction of glances and the play of fingers - the outstretched arm and splayed fingers of the bodyguard counter the raised fingers of the pleading hand extended by the hopeful kneeling man. It would be too much to expect of the painter that he should seek to depict the architectural marvels attributed by Rashid al-Din to Jamshid, such as the great aqueduct and his building of towns, but this material enriches the otherwise typical image of him as the teacher of crafts to mankind.

The other ancient Iranian king whose image is not entirely formulaic is Zahhak/Dahhak. Rashid al-Din's text is undeniably a rambling narrative, but the painting that accompanies it zeroes in on its most horrific element - Zahhak's definitive descent into the dark side following the fatal moment when Iblis kisses his shoulders. This is the earliest depiction of that fearful event in Iranian book painting. It has a dreadful immediacy and is full of drama. But the text does not go into any complementary detail, so that the image very much reflects the painter's imagination. Some later reader of the manuscript was clearly sufficiently upset by this story and its depiction to attempt to rub out the face of the miscreant monarch, something easily done by moistening a finger and rubbing Zahhak's face. An attempt was made to repair the damage but this was far too clumsily executed to achieve any success. Happily most of the painting was unaffected, and its principal features are plain except for the expression on Zahhak's face, which cannot now be reconstituted with certainty, though it seems to have been melancholy. The expressions of all the onlookers are sombre, and one can read sorrowful resignation, pity and barely suppressed horror in all these 
faces; one of the attendants has wrenched his face away from the scene and is looking the other way in his distress. The tall figure dressed in turban and blue robe and grasping a sword in a red scabbard, its cord wrapped round his right arm, gazes appalled at the tableau before him, his eyes wide with dismay. The foremost kneeling man - barefoot, half naked and with his hands bound behind his back - has his mouth open in shock as he stares death in the face. He is held down firmly by an attendant whose face has also been rubbed out. Behind him kneels the next victim, also bound and half-naked; his captor, too, has had his face rubbed out. Zahhak himself is stretched out at ease on his throne, legs negligently crossed, his left hand outstretched as he gives the order to proceed while the executioner looks down compassionately at his victim. Tubular extensions for Zahhak's surcoat accommodate the serpents sprouting in wide arcs from his shoulders. It may be significant that the margin is repeatedly broken in this picture, most noticeably by the turban ornament of the senior official nearest to Zahhak on the monarch's right, but also by the boot-tips of some of the attendants. This may be an attempt to trespass beyond the picture space into the space of those who view the image, and thus to involve them in this heart-rending spectacle. That device was destined to have a rich future. ${ }^{\text {liv }}$ The setting of this macabre scene is not fully defined, and indeed is downright ambiguous, for its left-hand side is neutral and presumably depicts an interior, while to the right of Zahhak there develops a curiously tentative, incomplete and scrubby exterior setting, whose scattered rocks and clumps of grass in front of the first victim - really more of a nod to a landscape than a real one - clearly indicate that this is happening in the open air, even though the attendants to Zahhak's right are standing on a floor rather than on the earth. The contradiction implied by the maroon canopy placed directly over the stunted landscape heightens this ambivalence.

Seen as a group, the images of the earliest mythical kings of Iran discussed in this paper could be regarded as repetitive and thus somewhat uninspiring. Nevertheless, they are 
full of pointers to the future of Persian painting, from the varied uses they make of landscape to the breaking of the frame, from the development of royal iconography to their evocation of the Mongol court and its ceremonies, from the confident wielding of the language of propaganda to an absorption in realia such as costume, weapons, luxury items, textiles and furnishings. This wealth of material is all the more striking given that the text, with its curiously genealogical bias, and its overload of information that does not lend itself to taking visual form, gave the painter little enough to go on. But that text, too, has its distinctive value for the evidence that it presents of an alternative history of the Pishdadian kings to that presented by other sources, notably Firdausi, whose Shahnama was gaining increasing traction at this very time. 


\section{BIBLIOGRAPHY}

Adamova, A.T. Medieval Persian Painting: The Evolution of an Artistic Vision, translated from the Russian and edited by J. M. Rogers (New York: Bibliotheca Persica, 2008).

Auld, S.J. "Characters out of context: the case of a bowl in the Victoria and Albert Museum", in R.Hillenbrand (ed.), Shahnama. The visual language of the Persian Book of Kings (Aldershot: Ashgate; Varie. Occasional Papers II), 99-116.

Blair, S.S. A Compendium of Chronicles: Rashid al-Din's Illustrated History of the World (London: The Nour Foundation in association with Azimuth Editions and Oxford University Press, 1995).

Blair, S. "Jamshid invents the crafts", in J. Gonnella and C. Rauch (eds), Heroic Times: A Thousand Years of the Persian Book of Kings (Munich and Berlin: Museum für Islamische Kunst. Staatliche Museen zu Berlin; Staatsbibliothek zu Berlin; Edition Minerva, 2012): 547.

Blair, S. “The Development of the Illustrated Book in Iran,” Muqarnas 10 (1993): 266-74.

Bosworth, C.E. “Tahmurath”, $E I^{2}$, X (Leiden: E.J.Brill, 1998): cols.110b-111a.

Brend, B. "Beyond the pale: meaning in the margin", in R.Hillenbrand (ed.), Persian Painting from the Mongols to the Qajars: studies in honour of Basil W. Robinson (London: IBTauris, 2000): 39-55.

Curtis, V.S. Persian Myths (London: British Museum Press, 1993).

Fahd, T. "Shaddad b. 'Ad”, EI², IX (Leiden: E.J.Brill, 1995): col. 169a.

Firdausi, Abu'l-Qasim. The Shahnama of Firdausi I, tr. A.G. Warner and E. Warner (London: Kegan Paul, Trench, Trübner \& Co. Ltd., 1903).

Fitzherbert, T. "Bal'ami's Tabari”. An illustrated manuscript of Bal 'ami’s Tarjama-yi Tarikh-i Tabari in the Freer Gallery of Art, Washington (F59.16, 47.19 and 30.21). Unpublished Ph.D. thesis, University of Edinburgh, 2001. 
Ghouchani, A. Persian Poetry on the Tiles of Takht-i Sulayman (Tehran, 1992).

Grabar, O. and S. Blair, Epic Images and Contemporary History: The Illustrations of the Great Mongol Shah-Nama (Chicago: University of Chicago Press, 1980).

Gray, B. "Shahnama illustration from Firdausi to the Mongol invasions", in R. Hillenbrand (ed.), The art of the Saljuqs in Iran and Anatolia. Proceedings of a symposium held in Edinburgh in 1982 (Costa Mesa: Mazda, 1994): 96-105.

Grube, E.J., et al., Cobalt and Lustre: The First Centuries of Islamic Pottery, ed. J. Raby (London: The Nour Foundation in association with Azimuth Editions and Oxford University Press, 1994).

Grube, E.J., Islamic Pottery of the Eighth to the Fifteenth Century in the Keir Collection (London: Faber and Faber, 1976).

Hillenbrand, R. "Propaganda in the Mongol 'World History", British Academy Review 17 (2011): 29-38.

Hillenbrand, R. “Holy Figures Portrayed in the Edinburgh Fragment of Rashid al-Din's World History", Iranian Studies 50/6 (2017): 843-71.

Hukk, M., H. Ethé, and E. Robertson, A Descriptive Catalogue of the Arabic and Persian Manuscripts in Edinburgh University Library. Hertford: Stephen Austin, 1925.

Ibn al-Athir, 'Izz al-Din, Al-Kamil fi'l-Ta'rikh, ed. Carl J. Tornberg. Leiden: E.J. Brill, 1851 onwards.

Justi, F. Iranisches Namenbuch (Hildesheim: Georg Olms Verlagsbuchhandlung, repr. 1963). Kadoi, Y. "Beyond the Mandarin square: garment badges in Ilkhanid painting", Hali 138: 4150.

Le Strange, G. The Lands of the Eastern Caliphate. Mesopotamia, Persia and Central Asia from the Moslem Conquest to the time of Timur (Cambridge:Cambridge University Press, 1905). 
Levy, R. (tr., revised byA.Banani), The Epic of the Kings. Shah-Nama the national epic of Persia by Ferdowsi (London and Boston: Routledge \& Kegan Paul).

Melikian-Chirvani, A. S. "Le Shah-name, la gnose soufie et le pouvoir mongol,” 222 (1984): 249-338.

Melikian-Chirvani, A.S. "Le Livre des Rois, miroir du destin”, Studia Iranica 17 (1988): 746.

Melikian-Chirvani, A.S. "Le Livre des Rois, miroir du destin. II - Takht-e Soleyman et la symbolique du Shah-Name", Studia Iranica 20 (1991): 33-148.

Milstein, R. “The Iconography of Moses in Islamic Art”, Jewish Art 12-13 (1987): 199-212. Melville, C. "Rashid al-Din and the Shahnameh", Journal of the Royal Asiatic Society, Series 3, 26/1-2 (2016): 201-14.

Melville, C. "Jame“ al-tavarik”, in Encyclopaedia Iranica XIV/5 (New York: Encyclopaedia Iranica Foundation, Inc., 2008): 462-68.

Natif, M. "Rashid al-Din's Alter Ego: The Seven Paintings of Moses in the Jami' altawarikh", in C. Burnett and A. Akasoy (eds), Rashid al-Din. Agent and Mediator of Cultural Exchanges in Ilkhanid Iran, Warburg Institute Colloquia 24 (London: The Warburg Institute, 2013): 15-37.

Oh, L.J., "The East Asian characteristics of Ilkhanid royal manuscripts”, Persica XIX (2003): 69-105.

Rice, D.T., ed. B. Gray, The Illustrations to the 'World History' of Rashid al-Din (Edinburgh: Edinburgh University Press, 1976).

Schroeder, E. “Ahmed Musa and Shams al-Din : A Review of Fourteenth Century Painting”, Ars Islamica VI/2 (1939), 113-42.

Schmitz, B. "A fragmentary mina' $i$ bowl with scenes from the Shahnama”, in R.Hillenbrand (ed.), The art of the Saljuqs in Iran and Anatolia. Proceedings of a symposium held in 
Edinburgh in 1982 (Costa Mesa: Mazda, 1994): 156-64.

Simpson, M.S., "The Narrative Structure of a Medieval Iranian Beaker,” Ars Orientalis 12 (1981): 15-31.

Simpson, M.S. The Illustration of an Epic. The Earliest Shahnama Manuscripts (New York and London: Garland Publishing, Inc., 1979).

Soucek, P.P. "The influence of Persepolis on Islamic art", Actes du XXIX Congrès des Orientalistes (Paris, 1975): 195-200.

Soucek, P.P. "Farhad and Taq-i Bustan: The Growth of a Legend", in P.J. Chelkowski (ed.), Studies in Art and Literature of the Near East in honor of Richard Ettinghausen (New York and Salt Lake City: Middle East Center, University of Utah and New York University Press, 1973): 27-52.

Soudavar, A. The Aura of Kings: Legitimacy and Divine Sanction in Iranian Kingship (Costa Mesa: Mazda, 2003).

Tabari, Muhammad b. Jarir al-, Ta'rikh al-rusul wa'l-muluk. Leiden, E.J. Brill, 1879 onwards. Tr. as The History of al-Tabari in 39 volumes. See in particular Volume I. General Introduction and From the Creation to the Flood, tr. Franz Rosenthal (Albany, N.Y.: State University of New York Press, 1989). 
NOTE.

It is a pleasure to devote this article to the memory of Edmund Bosworth in token of a friendship that lasted almost fifty years. By a fortunate conjunction, he supervised one of our doctoral theses $(\mathrm{RH})$ and examined the other $(\mathrm{CH})$, and he and his wife Annette were frequent guests in our house, as we were in theirs. The British Institute of Persian Studies was close to his heart, and in his diffident way he expressed that commitment in an unparalleled 40-year stint as editor of its journal, Iran. He was a major force in building up its reputation as one of the leading journals in Iranian studies in the widest sense. Hence it is thoroughly appropriate to publish this article there as a tribute to him.

This is also the place to acknowledge with deep gratitude the key role played by Sir Gerald and Lady Elliott in our ambitious joint project to publish the Edinburgh fragment of Rashid al-Din's World History in appropriate detail. Without their wonderfully generous and unstinting support we would not have been able to embark on this daunting enterprise.

${ }^{i}$ Edinburgh University Library, Ms. Arab 20; the basic publication is Rice, Illustrations.

ii Blair, Compendium, 24 and 27.

iii Natif, "Alter Ego"; Milstein, "Moses”, Hillenbrand, "Holy figures".

iv Ms. 20, f.2b.

${ }^{v}$ Ms. 20, f.3b.

vi Melville, "Rashid al-Din".

vii Gray, "Shahnama illustration"; Adamova, Medieval Persian Painting, 2-5 and 14-29. For the interest in the Shahnama in the early Ilkhanate see Melville, "Rashid al-Din", 202. viii Melikian-Chirvani, "Miroir du destin", xxx. 
ix Schmitz, "Bowl" and Grube, Cobalt and Lustre, 152-3, 208-9 and 244; Grube, Keir Collection, 199-200 and colour plate facing 200 (Faridun) and 248 and 250 (Rustam and Bizhan).

x Simpson, "Narrative structure".

xi Auld, "Characters".

xii Ghouchani, Persian Poetry; Melikian-Chirvani, "Miroir du destin. II”, 54-74.

xiii The best general account of them is that of Simpson, Manuscripts, though it is

limited to a select group, excluding for example the Shahnama manuscripts in St Petersburg and Istanbul, the 1341 Inju copy, the so-called Stephens Shahnama and the one in the Cama collection.

xiv The Freer Bal'ami has a further ten Shahnama scenes (Fitzherbert, Bal 'ami's Tabari”).

${ }^{x v}$ Blair, "Development".

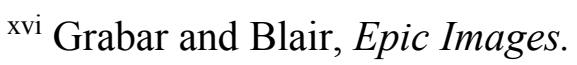

${ }^{x v i i}$ It is interesting to note where such Iranian material was inserted. In the case of al-Tabari, the account of Oshajanj/Hushang (tr. Rosenthal, 341-2) follows those of Adam, Cain and Seth; after Oshajanj the narrative turns to Jared and Enoch/Idris before embarking on the story of Tahmurath (tr. Rosenthal, 344-5). More space is then allotted to revisiting the stories about Jared and Enoch/Idris, followed by Methuselah, Lamech and Noah, who lived in the time of Bewarasb (Zahhak). It is at this point that al-Tabari devotes a whole section to Jamshid and Zahhak (tr. Rosenthal, 348-52). As for Ibn al-Athir, the material on the mythical Persian kings is also interspersed with Biblical figures like Seth and Noah, and can be found at I:61 (Tahmuras), 1:64-6 (Jamshid) and 1:74-7 (Zahhak).

xviii See Hukk, Ethé and Robertson, Catalogue, 15-17.

xix The story of Abraham extends to 53 lines; that of Moses occupies 202 lines.

xx Blair, Compendium, 21. 
${ }^{\text {xxi }}$ Ms. 20, f. 2a.

xxii Hushang (Haoshanha) was the first king of the mythological dynasty known as the Paradata dynasty (Pishdadian in the Shahnama); Curtis, Persian Myths, 25 and 31. He is the grandson of Kayumars/Kiyumars and the son of Siyamak. He is praised for his achievements in developing civilisation: ibid., 31. Rashid al-Din says (f. 2a) that some assert that Hushang was Mihla'il, others that he was Arpachshad, the ancestor of both Zahhak and Faridun. xxiii “Eternal Wisdom"; for a discussion of this, see Melville, "Rashid al-Din”, 207. ${ }^{\text {xxiv }}$ Here f. $2 \mathrm{a}$ ends.

${ }^{\mathrm{xxv}}$ Ms. 20, f. 2b. The section on Hushang in the Edinburgh fragment closely echoes Baidawi's Nizam al-Tawarikh and part of the Persian text of Rashid al-Din as presented in the Tehran edition by M.Raushan (Melville, "Rashid al-Din", 208). But it leaves out key elements of the story of Hushang as given, for example, by Firdausi.

${ }^{\text {xxvi }}$ Ms. 20, f. 2b. Tahmuras, the son of Hushang, was known as the 'Demon-binder'; Levy, Shah-nama, 9.

${ }^{x x v i i}$ His name appears in the Avesta I as Takhmo urupa azininavea ('the strong one in the fox-skin'): cf. Bosworth, “Tahmurath”, 110b. Justi writes his name as Tayma - urupan: Justi, Namenbuch, 320).

${ }^{\text {xxviii }}$ Melville cites here the British Library ms. (Ms. Add. 7628, a Persian version of Rashid al-Din's text, undated but formerly in the library of Shah Rukh): "he built Kuhandiz [Ar. Karhardar] in Marv" (Melville, "Rashid al-Din", 208; cf. ibid., 204). This manuscript is accessible at http://www.bl.uk/manuscripts/FullDisplay.aspx?ref=Add_MS 7628. It is obviously related closely to the Edinburgh fragment in this portion of the text. The details of that relationship are an obvious topic for future research. 
xxix The text has M*hrin; the British Library ms has Mihrin, and Saduyeh for Saruyah (Melville, "Rashid al-Din", 208). The Marbin district to the west of Isfahan was the site of an ancient fire- temple, built by Tahmuras, 'the demon binder'; Le Strange, Lands, 206. ${ }^{x x x}$ The text has 'to them'. xxxi The sense demands some such phrase as "the wealthier people" here. xxxii Ms. 20, f. 2 b. xxxiii That is, Ctesiphon. xxxiv Taysafun in the text. xxxv "He of the ten vices".

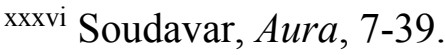
xxxvii Soucek, "Persepolis". xxxviii Soucek, “Taq-i Bustan”. xxxix These are indicated in the present article by multiple dots.

${ }^{\mathrm{xl}}$ New Persian Bewarasp/Bewarasb ('master of ten thousand horses'); al-Tabari, tr. Rosenthal, 344, n.1024.

xli Cf. Fahd, "Shaddad b. 'Ad", with the information that he is associated with the city of Iram Dhat al-'Imad, a reference that takes the reader back to the current beginning of this manuscript. xlii Namely, "he of the ten vices". xliii The illegible text here presumably referred to the familiar tradition that two openings appeared in his shoulders from each of which a serpents grew that had to be fed daily with human brains. Cf. the account by Firdausi, Shahnama, tr. Warner, I, 138-9.

${ }^{\text {xliv }}$ For a representative selection, see the Cambridge Shahnama database: shahnama.caret.cam.ac.uk xlv This arrangement is found only once more in the entire manuscript, on f.122a. 
xlvi There are two further images of ancient Persian kings - Minuchihr and Luhrasp - and the remaining enthronement scenes are all associated with the Saljuq kings.

xlvii The use of such chest designs is not confined to the kings; one of Tahmuras's attendants sports a similar design. For further discussion of this motif, see Kadoi, "Mandarin square". xlviii Oh, "Characteristics".

xlix The bodyguard attending Jamshid has his bunched hair, in the form of a curled plait, covered with the same patterned cloth that is used for the brim of his hat: clearly a sharp dresser.

${ }^{1}$ The commonest design features tiny golden stars against a bright blue background.

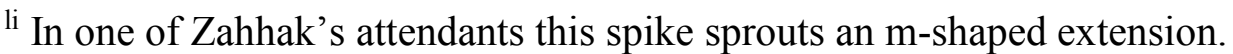

lii But not proving; some of these forms may reflect the artist's fantasy or his ignorance of the finer details of court and military protocol. Eric Schroeder's valiant attempt to make sense of the plethora of headgear in Ilkhanid painting - he studied no less than 127 hats - ended in resounding failure. See Schroeder, "Ahmad Musa and Shams al-Din”, 122-3 and figs. 1-2. liii Blair, "Jamshid".

liv Brend, "Beyond the pale". 
1 Hushang. Rashid al-Din, Jami` al-tawarikh, Edinburgh University Library (Arab ms. 20), fol.

2a (by permission of the Edinburgh University Library)

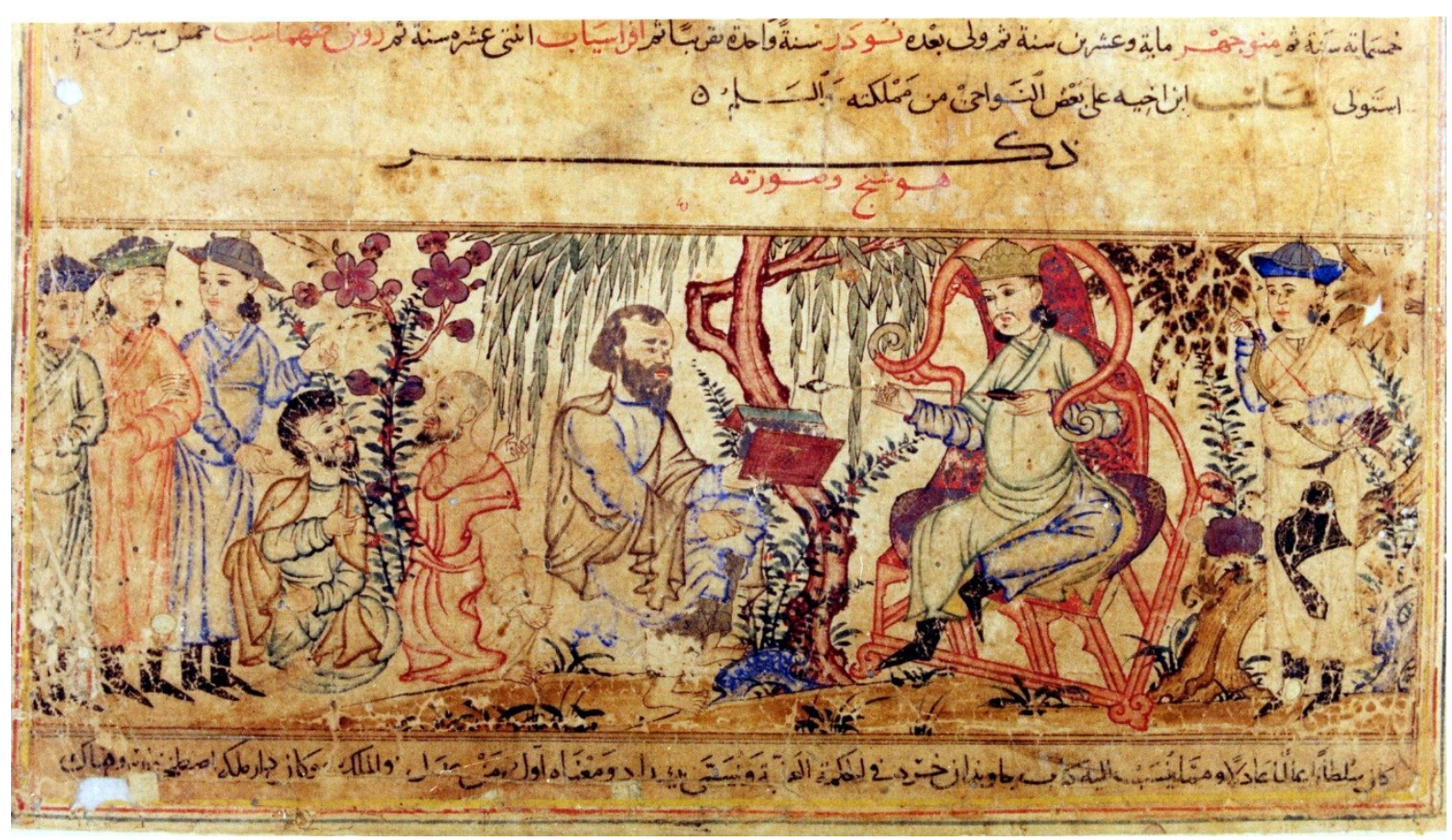


2 Tahmuras. Hushang. Rashid al-Din, Jami 'al-tawarikh, Edinburgh University Library (Arab ms. 20), fol. 2a (by permission of the Edinburgh University Library)

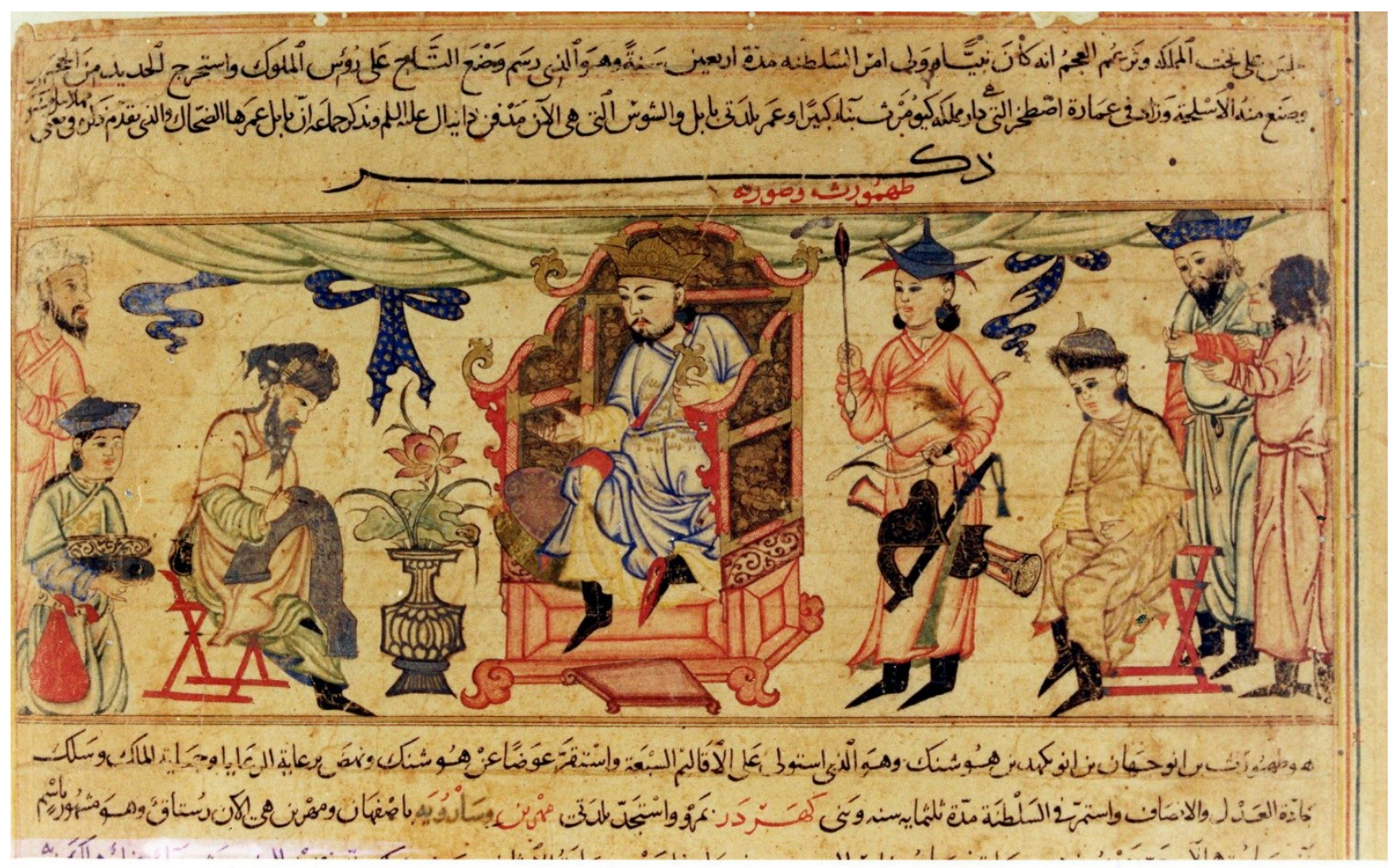


3 Jamshid. Hushang. Rashid al-Din, Jami`al-tawarikh, Edinburgh University Library (Arab ms.

20), fol. $2 b$ (by permission of the Edinburgh University Library)

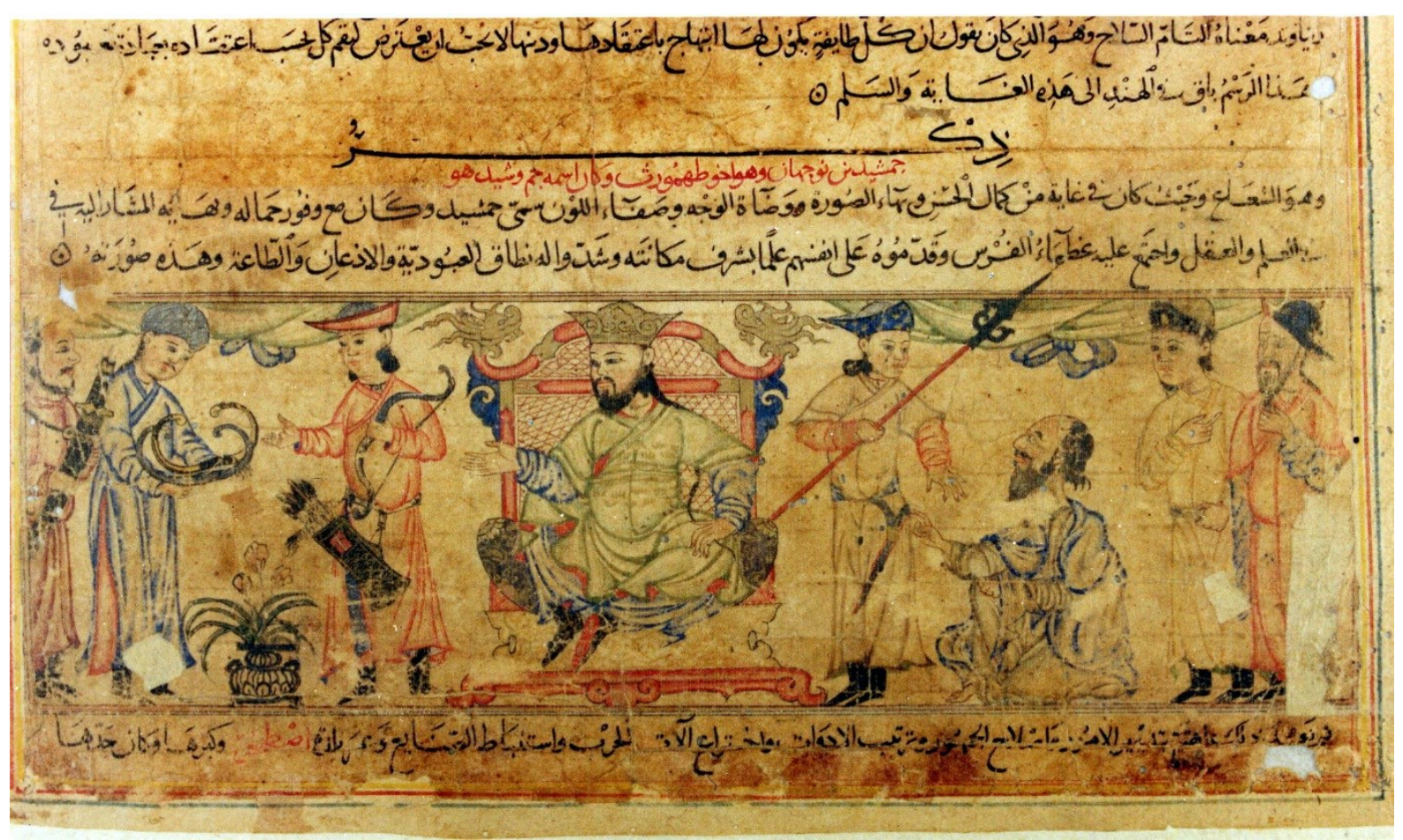


4 Zahhak. Hushang. Rashid al-Din, Jami 'al-tawarikh, Edinburgh University Library (Arab ms.

20), fol. 3a (by permission of the Edinburgh University Library)

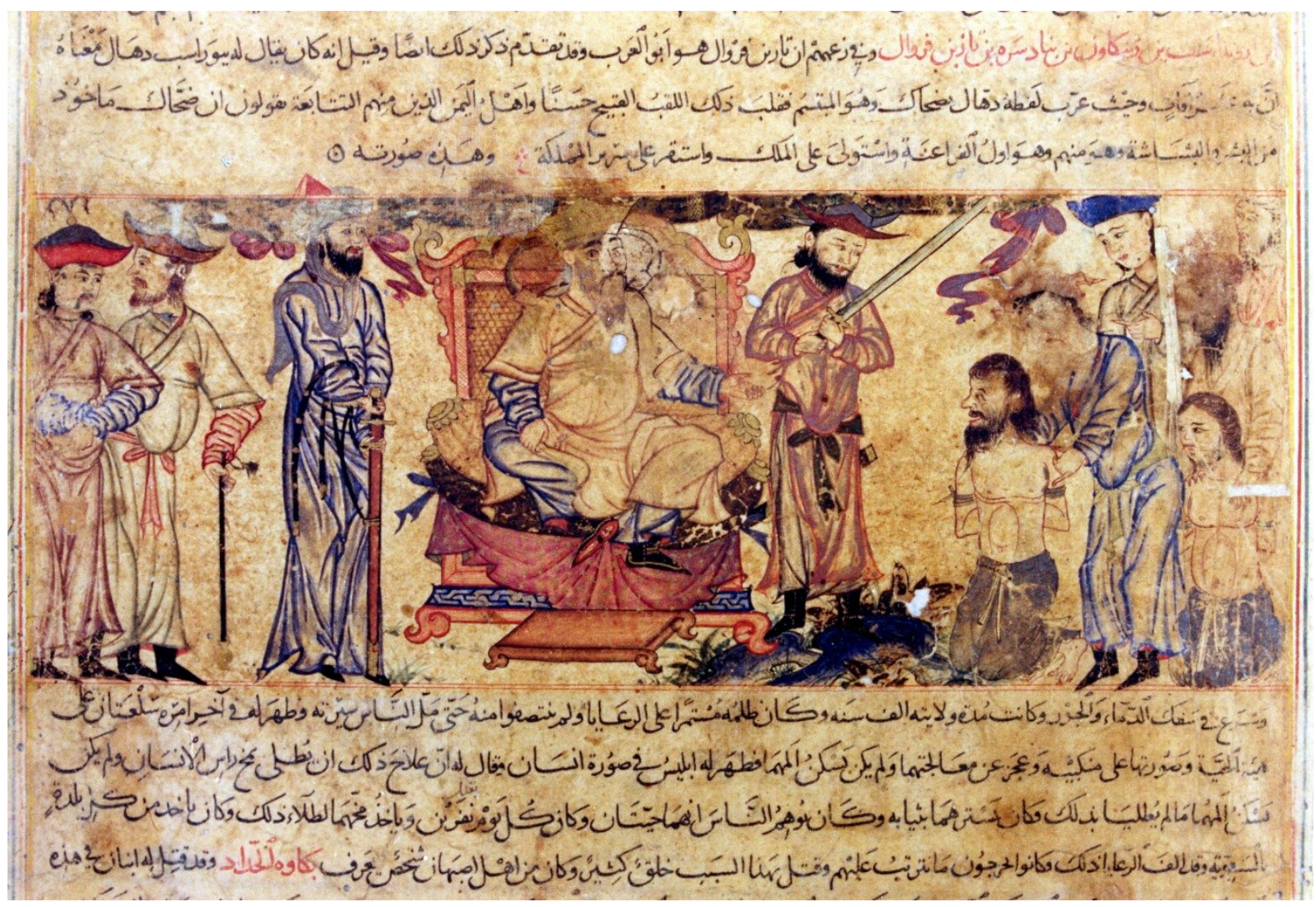

